\title{
Lynn, Thomas Jay. Chinua Achebe and The Politics of Narration: Envisioning Language. Palgrave Macmillan, 2017.
}

\author{
Fatma Chenini
}

Thomas Jay Lynn's book examines Chinua Achebe's language and narration in relation to the intersections of African culture - especially the oral traditions of his native Igbo community - and Western novelistic forms in a postcolonial critical framework. Although the title of the book alone does not indicate the importance that Lynn ascribes in his analysis to the specifically African elements in Achebe's language, the cover design is telling: the background photo is of a giant traditional African mask - one of the most typical visual representations of African art. Although the mask's lineaments are not apparent because the title and the subtitle cover them, this may be understood as a visual allusion to the African oral tradition, which greatly informs Achebe's language, and this is precisely what Lynn is striving to illuminate for his readers.

According to the author, Achebe invents a literary technique which enables him to draw on the characteristic syntax of an African language within English. Lynn argues that Achebe's new technique is a form of "revolution" against denigrating perceptions of Africa in Western literature, since "it is through words that colonial culture inscribes its presumed superiority over the African culture" as Simon Gikandi remarks (qtd. in Lynn 2). This technique also helps his readers to have a historical, psychological, and social insight into the mindset of his fictional characters, through which Achebe seeks to depict the colonial and postcolonial experience of African people. Achebe's mastery of both the English and the Igbo enabled his texts to traverse the boundaries of Africa and reach global audiences, which accounts for the fact that his "dignified narrative voice" (1) and his way of interweaving his native African language and traditions with Western literary conventions have become widely admired.

In the first chapter, "An Adequate Revolution: Achebe Writes Africa Anew," Lynn demonstrates how language is one of the serious impediments that prevented Europeans from dealing with and understanding Africans properly, which was responsible for the representations of Africans "through animalistic and savage imagery" (25). Lynn opens his chapter with a question from Achebe's first novel, Things Fall Apart: "Does the white man understand our custom about land?" to which the answer comes in the form of another question: "How can he when he does not even speak our tongue?" These questions suggest how the language barrier 
created a gap between the two cultures, and how it prevented the Europeans from exploring the inner lives, customs, and the psychic complexities of the African individual, which led eventually to misrepresentations of Africa. Achebe attributes this dehumanization of Africans to the racist Western ideology according to which Africa is to be considered "as a foil to Europe" (qtd. in Lynn 32), whereby the Western colonizers justified their exploitation of the continent's natural resources. Lynn quotes Achebe as saying: "[Some of] the first Europeans [who] came to Africa ... persuaded themselves that Africa had no culture, no religion, and no history. It was a convenient conclusion, because it opened the door for all sorts of rationalizations for the exploitation that followed" (25). As the chapter proceeds, Lynn explains how Achebe uses language in his novels to heal the damage caused by the West's lack of knowledge of African languages and culture by inserting dialogues in Igbo or integrating proverbial elements, as Achebe believes that the traditional Igbo proverbs are a powerful mode of discourse, which contributes to the revelation of the African voice and shape in Anglophone African literature. The Igbo perspective is central to Achebe's writing because it supports the principles of negotiation and the possibility of multiple points of view in discourse.

Lynn explains that Achebe's narration draws upon a contrapuntal approach embracing multiple concepts, subjects, and viewpoints rather than privileging one over all others, which is illustrated in the Igbo proverb "Wherever Something Stands, Something Else Will Stand Beside it" (qtd. in Lynn 6). Achebe uses this approach in response to Western texts such as Joseph Conrad's Heart of Darkness, which represents the Africans as savages incompatible with the modern civilization of the West. By contrast, Achebe's endeavor is to counteract the hierarchical binary oppositions associated with the colonial presumption of superiority. Thus, his aim is to eliminate a binary opposition of superiority vs. inferiority, or the civilized vs. the savage, and replace it by a sense of diversity which draws upon the philosophy of balance in Igbo culture. According to Lynn, the Western binary dualism is ponderously visible in "Western chauvinism toward non-Western peoples," or in what Edward Said calls Orientalism, which "is never far from what Deneys Hay has called the idea of Europe, a collective notion identifying us Europeans as against all those non-Europeans ..." (qtd. in Lynn 7). Through his narration, which is firmly grounded in Igbo culture, Achebe is able to obviate the prejudices of European writers by creating a novelistic form that resists the "one-way traffic" (32).

In the second chapter, "Of Flight, Fraud, and Freedom: Achebe's Political Tricksters," Lynn focuses on the African political challenges in the context of which Achebe's fiction was written. Lynn contends that the trickster has been adapted by modern writers, like Achebe, to represent the resistance of African communities to colonialism in the past, as well as injustice and corruption in the present. 
Moreover, the figure of the trickster also serves to strengthen the presence of the elements of traditional African storytelling in the modern novel. Achebe affirms this importance in his novels by his repeated allusions to the trickster figure, which he relates to African political challenges. First, in Things Fall Apart, he chooses the folktale about the tortoise and the birds, which depicts the struggle against colonialism in Africa from an African perspective; second, in A Man of the People, he represents the political career of Chief Nanga as that of a trickster, whereby he exposes the domination of corruption and the sources of disillusionment in postindependent Africa; and third, in his final novel, Anthills of the Savannah, Achebe uses another tale of the trickster tortoise to show the crisis of authoritarian rule in Africa. Thus, the trickster figure, as one of the main characters in Achebe's fiction, helps to overthrow the hegemony of binary narratives, as the trickster functions as a combination of heroes and villains, or as a "beloved rascal," whom we appreciate even despite their apparently evil deeds.

The subsequent chapters focus mainly on different dimensions of Achebe's language in which he tells his story of Africa. Lynn goes on to elaborate on Achebe's effort to link the past with the present by combining elements of oral storytelling with written literature to produce a work that creates a link between the historical and the contemporary, and at the same time alters our understanding of African histories. Lynn appears to be in full agreement with Achebe's views, and so he neglects to mention instances of counter-criticism where Heart of Darkness is interpreted from different perspectives than what urged Achebe to start writing in the first place. Such a critical approach can be seen in Edward Said's "Two Visions in Heart of Darkness," where he argues that Conrad's narration and his dehumanizing representation of Africa is due to the sovereign historical force of imperialism and its system that represents and speaks for everything within its sovereignty. Said explains that Conrad's narrative is contingent on and limited to a situation in which his narrator, Marlow, recites his adventures to a set of British listeners at a particular time and in a specific place. Said adds that Conrad's narrations show that neither Conrad nor Marlow could imagine an alternative world to imperialism, where the natives may be able to put an end to the European colonization and achieve independence.

As a consequence of his long teaching experience in the field of literature of Africa and that of the diaspora, we find that Thomas Jay Lynn is captivated by Achebe's language and narrative methods, which accounts for the sophisticated innovativeness of his novels. Lynn's appreciation of Achebe's language and African literature in a broad sense led him to write a chapter, at the end of his book, about classroom approaches to Achebe's fiction, explaining that these approaches should be based on "multidimensional response," since Achebe's work encompasses 
widely discussed topics such as "colonial otherness," "postcolonial agency," and "transnational perspective." Furthermore, Lynn also sees that the comparative approach is important in dealing with Achebe's texts, since it highlights "conflicts, motivations, and themes in a story that would be undervalued or hidden without the reciprocal influence of the other text" (146). Thus, Chinua Achebe and The Politics of Narration: Envisioning Language is a useful, comprehensive, and accessible book for teachers, scholars, and students who wish to familiarize themselves with African literature in general, and a detailed study on Achebe's use of language in particular. 